Anna Obara-Pawłowska

(Marie Curie-Skłodowska University in Lublin, Lublin)

ORCID: 0000-0002-5507-4336

anna.obara-pawlowska@poczta.umcs.lublin.pl

\title{
ECONOMIC CONTENT IN THE NARRATIVES OF WŁADYSEAW I THE ELBOW-HIGH'S DIPLOMAS - CLICHÉD FORM RECORDS OR A SYMPTOM OF AWARENESS OF THE MEDIEVAL RULER?
}

\begin{abstract}
The article analyzes the economic content that appeared in the narratives of Władysław I the Elbow-high's documents. References to the economic sphere occurring there were divided into two types. The first one contained information on the economic condition of an area, first and foremost about the destruction or war devastation that hit a given region or town. The second type justified ruler's decisions, a desire to reform or to increase the benefits of the monarchy and his subjects. On the basis of the data obtained, an attempt was made to comment on the economic awareness of the ruler.
\end{abstract}

Keywords: narratives, economy, Władysław I the Elbow-high, Middle Ages, economic awareness

doi: $10.2478 /$ sho-2020-0002

\section{INTRODUCTION}

One of the most difficult tasks faced by a researcher dealing with medieval economy is to define the scope of the economic awareness of the rulers. I mean here especially giving an unequivocal answer to the question whether, when making a specific decision in the field of economy, the decision-maker had in mind only the achievement of immediate financial benefits (which is to prove against thinking in economic terms [Tomaszewski J. 1981: 94; Kutrzeba S., Ptaśnik J. 1910: 10], or there was, behind specific decisions, a vision of the implementation of targeted plans aimed at intensifying the economy of a given town, region or country. This difficulty results from the lack of an appropriate category of sources in the Middle Ages, 
such as various programs, plans and economic analyzes or theoretical reflection on the role and tasks of various decision-making centers in the economic sphere. Basic information on the economic decisions of the late medieval monarch is provided by the diplomas issued by his office. It is worth noting that the majority of these acts related to economic matters, such as permits for establishment of new villages, permits for foundations of properties under German law, trade privileges, customs exemptions, monetary regulations, and finally confirmation of previously granted economic privileges. The aim of this article is an attempt at formulating an opinion on the economic awareness of medieval ruler on the example of the actions of Władysław I the Elbow-high and his immediate surroundings, based on the analysis of the statements contained in the narratives of documents indicating the will to reform, and improve the economic condition of a given property or area, or describing the current state of the region's economy. It should be decided whether the appearance of such references was the intention of the issuer of the document, being aware of the importance of economic matters for the proper functioning of his rule, or whether we are dealing here with a thoughtless duplication of form patterns reflecting only stereotypical notions about the monarch's obligations ${ }^{1}$. Equally important will be the attempt to answer the question of how the use of certain phrases was understood, what exactly - or anything at all - was meant in such cases? Some time ago, Stanisław Kuraś, speaking about the role of medieval documents in social life, stated that even without real legal significance, they could have a symbolic meaning, important from the point of view of both the recipient and the issuer [Kuraś S. 1971: 72]. The narratives seem to be of particular interest in understanding the ruler's economic motives. They presented the circumstances that existed before the document was issued leading to the taking of a given action [Bielińska M. 1967: 50; Maleczyński K., at al. 1971: 24]. The issue of the role and significance of economic motifs in the narratives of medieval monarchs' documents has not been the subject of separate analyzes. In recent years, research has been undertaken on the economic content expressed by individual Polish rulers, including the protagonist of this article [Nowakowski T. 2007: 91-105; Obara-Pawłowska A. 2014b: 1049-60].

The analysis of the content of the surviving documents of Władysław the Elbow-high showed that there were references to economic issues in

1 The content included in the narratives of a part of documents issued by Ottokar II of Bohemia was assessed this way [Barciak A. 1988: 42]. 
the narratives of almost 30 of them ${ }^{2}$. At first glance, it may seem a small number if we take into account the total number of the surviving diplomas that were prepared in the monarch's office. However, they stand out from the rest of the narratives indicating the willingness to pay the service of faithful subjects as the main motive for taking a given action. The economic content of the narratives of Władysław the Elbow-high's documents can be divided into two types, sometimes appearing together. The first contained a short description of the current economic situation in a given area, which prompted the ruler to take a specific action. The second type explained the reason for a given decision of the ruler by referring to such categories as desire to reform, improve, elevate the economic condition or increase the benefits of the ruler, subjects and the monarchy.

In the Elbow-high's documents one can find references to the devastation and destruction of a specific area as a result of war. In this way, a justification was made to free the inhabitants of Poznan from paying the duty in the territory of Władysław's rule in February 1298. The prince indicated that the town of Poznan in magna sua parte per gwerras est vicia$t a[\mathrm{KDW}, 2: 273]$. On the basis of this information, Tomasz Jurek stated that before February 1298 Poznan suffered an attack and sacking by the Silesian army. This attack was supposed to be a retaliation expedition for the attack of Władysław, assisted by Hungarians, on Silesia in the previous year [Jurek T. 2006: 70]. Thus, the researcher accepted the statement previously expressed by Władysław Karasiewicz [1965: 269-70] that in the discussed case the words about the destruction of the town were not only a form phrase, but a reflection of the situation [Jurek T. 2005: 189; 2006: 70]. It should be remembered that during his first reign in Wielkopolska, Władysław the Elbow-high did not manage to maintain security in the region, and his rule was accompanied by increasing chaos and helplessness, especially in terms of road robbers. Difficulties in ensuring order by the ruler are confirmed by documents from 1298-99, in which the Elbowhigh granted the inhabitants of Wiekopolska urban centers, i.e. Poznań, Pyzdry, Kalisz and Gniezno, the right to pursue and capture criminals [KDW, 2: 777, 820].

2 This list does not include the document dated to 10 February 1290 whose alleged receiver - Krystyn from Goraj, obtained right to charge duty in the territory of entire Kraśnik, while the inhabitants of the Lublin lands were exempt from any fees for a period of 30 years. The issuer referred there to the devastation of this area due to Tatar raids [KDM, 2, 615]. This document is a forgery [KDM, 2: 288; Preissner A. 1965: 222, note. 269; Myśliński K. 1964: 18]. 
A more extensive thread relating to the poor condition of Poznan appeared in the narrative of the document from April 1316, in which the ruler renewed and confirmed the privileges previously obtained by the physician Mikołaj. The prince stated that the said recipient had lost the diplomas previously awarded to him as a result of the devastation of Poznan by domestic and foreign enemies (Cum per magnam depopulacionem et impyam devastacionem civitatis Poznaniensis, infinite res et varie fuissent perempte hostiliter per manus terrigenarum et inimicorum diverse nacionis, inter quas honorabilis viri ac famosi magistri Nicolay phisici multe res, maxime privilegia continencia donaciones, confirmaciones hereditatum domini regis pie recordacionis Premisly, et immunitates earumdem ipsius domini regis et nostras, proch dolor, sunt recepta et amissa) [KDW, 2: 982]. This information can be related to the fights in Poznań between opponents and supporters of the Głogów princes, which took place after the death of Henry IV. As a result of military operations, the cathedral and the houses of Poznan canons located nearby were damaged ${ }^{4}$. Moreover, other sources from that period attributed the persecution of the local Polish population to the Germans advising the young rulers of Głogów. The author of the Poznan yearbook emphatically stated that the Germans from the circle of the princes advised: totam gentem Polonicam exterminarent, ecclesiasticas personas, quam seculares milites [Rocznik kapituty poznańskiej: 55]. This statement would be in line with the note contained in the document of 1316 about the damage suffered at the hands of enemies coming from different nations. The confirmation of the possession of the court physician of successive Wielkopolska Piasts [Skulimowski A., Skulimowski M. 1958: 285-90] and the permission to transfer several villages belonging to him to German law, was part of the program of rebuilding the economic base of the capital of Wielkopolska [Obara-Pawłowska A. 2014a: 228].

The theme of the destruction suffered by Wielkopolska also appeared in the narratives of other documents. In December 1315, the prince granted the bishop town of Słupca the right to organize a fair. The prince justified this decision with the desire to reform the center after various kinds of disturbances experienced by Wielkopolska. It is worth quoting a long-

\footnotetext{
${ }^{3}$ About the ongoing fights at that time see: Nowak T. [1989: 34-5]; Jurek T. [2006: 20326].

4 Annales [63-4]. More see: Potkański K. [1965: 498-9]. Information about devastations that the Church of Poznań suffered was conveyed in the document of Wojciech, the landlord of Krosna who, in order to make up for the losses, pledged his own village Żabikowo to the bishop of Poznan for 3 years.
} 
er passage from the Elbow-high's document: [...] civitas prefata Slupcza, post varia disturbia terre Polonie hactenus perpessa, aliquatenus valeat reforma$r i$, damus et concedimus eidem domino episcopo et suis civibus de Slupcza annuale forum, quando elegerint, infra triduum annuatim plenam potestatem perpetuo imponendi [...] [KDW, 2: 979]. The authors of the monograph on the history of Słupca indicated that the phrase about destruction (post varia disturbia terre Polonie hactenus perpessa) might have concerned some unknown losses that the town faithful to Władysław experienced during the war with the Głogów princes [Dzieje Stupcy 1996: 50]. Such devastation, unnoted by other sources, could indeed have taken place. However, one may try a slightly different interpretation of the words of the document. There is no mention here that the riots reached Słupca itself. It was clearly stated that it was the Wielkopolska region that had experienced these unrest. Although the owners (the bishop of Poznań) and the town's inhabitants were the beneficiaries of the right to organize the annual fair and the related customs exemptions, the entire region was to be indirectly benefited.

In August 1324, the king, giving the Cistercians in Ląd the right to build a new or repair an old water mill near the castle in Pyzdry, mentioned the losses suffered by the gray monks as a result of the royal expedition (propter nicham desolacionem et destructionem quam fecimus Domui Lendensi Ordinis Cysterciensis cum essemus cum exercitu in Polonia) [KDW, 2: 1044]. This narrative may refer to the events that took place in Wielkopolska 10 years earlier. It is possible that during the march or stay of the Elbow-high's troops in Słupca or Pyzdry ${ }^{5}$ in $1314^{6}$, the property of the Ląd monastery located in the vicinity of these two centers ${ }^{7}$ may have suffered.

${ }^{5}$ Historians disagree as for the duration of the fights and the character of forces involved in Wielkopolska. According to Tomasz Jurek, when in the middle of August 1314, the Elbow-high arrived to Wielkopolska, the fights had already stopped, and Głogów princes had been removed from power by the inhabitants of Wielkopolska themselves [Jurek T. 2006: 222-3]. Karol Tanaś assumes, in turn, that between August and November 1314, troops faithful to the Elbow-high were conducting an action against resistance to his rule [Tanaś K. 2006: 60].

${ }^{6}$ In January 1314, the presence of the Elbow-high was confirmed in Słupca [KDW, 2: 964-5]. In August and September 1314, the prince stayed in Pyzdry where he issued documents for local townspeople [KDW, 2: 971] and for the gray monks in Ląd, by which he confirmed the bestowal obtained by the monastery during the reign of Wacław II [KDW, 6: 84].

${ }^{7}$ Location of the Wielkopolska complex of Ląd monastery properties see: Wyrwa A.M. [1995: 120, ill. 26: Uposażenie ziemskie klasztoru lądzkiego od końca XII do końca XIV wieku w kluczu wielkopolskim]. 
In June 1326, Master Jan received from King Władysław the Elbowhigh an iron foundry called Ruda near Rogoźno. It was to be rebuilt post longam desolacionem [KDW, 2: 1068]. It is difficult to determine what caused the destruction or abandonment of the said foundry. The existence of metallurgical facilities in the area of Ruda, which could be used by the founders and residents of nearby Rogoźno, was confirmed as early as 1280 [Brust M. 1986: 33; 1993: 26, 30; 2010: 74-5]. It is possible that the iron foundry fell into disrepair due to the problems with obtaining iron from the local ores. The ores exploited in Poland at that time were usually poor bog iron ores with a low iron content [Hutnictwo na ziemiach polskich 1992: 51]. Also Ruda, located near Rogoźno, did not bring much income to its owners [Zientara B. 1952: 208; 1954: 88-9].

In the fall of 1327, King Władysław took care of the estates of the monasteries in Obra, Paradyz and Zemsko because of their destruction and devastation, in order to facilitate the reorganization of these estates (ex officio nobis disposicione divina concesso paupertatem ac defectus quorumlibet nobis subiectorum sollicita observacione discernere cupientes, ac maximam desolacionem domorum et claustrorum, scilicet in Paradiso, in Zambrusco et in Obra perpendentes, et ut abbates in predictis claustris una cum fratribus et omnibus villanis suis eo melius et facilius hereditates suas locare valeant) [KDW, 2: 1085]. In this case, it is easiest to link the destruction to the Elbow-high's expedition to Brandenburg in February 1326, when the king's army reached Frankfurt, passing through the area of the Międzyrzecz castellany ${ }^{8}$. In the countries of the Reich, this invasion was remembered for a long time because of the presence of Lithuanian troops supporting the king of Poland. They were to wreak enormous havoc on the Cistercian monasteries in New March (three male and two female monasteries) ${ }^{9}$. The monasteries in Zemsko and Paradyż were located in the Międzyrzecz castellany, while the Cistercians from Obra owned the set of estates located there ${ }^{10}$. Some historians do not exclude a possibility that during the march of Polish-

${ }^{8}$ Prevalent in historiography is a belief that an effect of this war was regaining Międzyrzecz castellany by Poland [Zajączkowski S. 1929: 79, 87; Gładyszówna J. 1933: 28; Rymar E. 1979: 494-5; 2000: 35, 42]. The mentioned area could have come under the rule of the Elbow-high in the years 1321-1323, and in 1326, the army subordinated to the king of Poland set off to Brandenburg exactly from Międzyrzecz [Olejnik K. 2002: 63].

${ }^{9}$ Petri de Dusburg, Chronicon terre Prussiae [193]. General narratives about destruction of local monasteries were also conveyed by the author of Chronicon Aulae regiae [278].

10 This was the Lotul group consisting of the settlements located around the contemporary village of Lutol Mokry [Wyrwa A.M. 1995: 151; Stownik historyczno-geograficzny... 2020: entry: Obra]. 
Lithuanian troops through this area, the monastic property was destroyed, and the later declarations of royal protection constitute a form of compensation for the harm done [Gładyszówna J. 1933; Wyrwa A.M. 1999: 374; Rymar E. 2000: 35]. In the case of the gray monks from Obra, it was the second diploma that guaranteed them royal protection. Three years earlier, in 1324, the king took care of the monastery and granted economic immunity to its estates [KDW, 2: 1043]. These two diplomas, issued not long one after the other, may prove the monarch's great interest in the economic condition of this monastic institution. It could have resulted from a real concern and a desire to rebuild the abbey's property, which - compared to other Cistercian houses in eastern Wielkopolska - belonged to the poorest [Wyrwa A.M. 1995: 154]. The patronage of the monarch was not only to ensure the loyalty of the ruler's beneficiaries, but also guaranteed free economic development of the monastery estates, strengthening the economic potential of the newly acquired lands.

There is also a document from May 1311, issued for the courtier Zdziesław, who obtained immunity for three villages near Lublin. The narrative clearly indicates that these settlements remained mostly deserted, abandoned ([...] quae [3 villages -A.O] sunt pro maiori parte desertae [...]) [ZDM, 4: 891]. The reference to the abandonment of property did not have to be only a rhetorical turn. The Lublin region, which was the eastern border of the Polish state, remained the least developed part of Władysław's domain, as it experienced plundering invasions by neighbors throughout the $13^{\text {th }}$ century, which inhibited the economic development of this area ${ }^{11}$. The information about the depopulation of the indicated properties could refer to the economic regress of the region being a result of the destruction during previous military operations.

Correlating the above more or less laconic descriptions of damage with specific events allows us to state with high probability that they were reflected in reality. The analyzed fragments of the narrative also indicate that the ruler and his advisers saw the need to improve the condition of the economy in a given area. In the indicated cases, one can also find references to the idea of peace, understood as ensuring the safety of subjects mainly to church institutions - by the monarch's authority [Kotecki R. 2020: 27, 54-74]. The ruler's fulfillment of this obligation not only protected the property belonging to the Church, but above all contributed to the proper development of the economy of the state or its particular regions.

${ }^{11}$ See the further part of these reflections. 
A question that is difficult to answer satisfactorily is: why the information about the devastation or depopulation contained in the narratives of Władysław the Elbow-high's documents appear mainly in the context of Wielkopolska. Most of the reign of this ruler was marked by intensive efforts to gain and maintain control in various areas. More than once, the monarch was forced to repel attacks from external enemies. Such actions must have caused losses and devastation of properties located in various parts of his domain. Perhaps the references mainly to one district of the monarchy were a coincidence and resulted from the fact that diplomas containing phrases similar phrases to the aforementioned ones, but intended for recipients from other Polish lands, have not physically survived to our times.

In the narratives of Władysław's documents, more frequent are records of the ruler's desire to reform, improve the economy and increase the benefits or incomes of the beneficiaries or the entirety of the subjects as a result of making certain royal decision. They were articulated with the use of such phrases informing about the will to reform, improve, ameliorate, change for the better, i.e. reformatio/reformare ${ }^{12}$, melioratio/meliorare ${ }^{13}$, locare $^{14}$, ampliatio ${ }^{15}$, restauratio ${ }^{16}$, as well as all kinds of references to increase, multiply (augere, amplificare, multiplicare), understood in the most material way [Nowakowski T. 2007: 103], utilities, benefits or income (utiltates, proventus, reditus) ${ }^{17}$ [KDW, 2: 596; KDW, 6: 59; CDP, 1: pars 2, 107]. One

12 The discussed narratives referred to the following constructions: pro reformacione [KDW, 2: 760], melius reformetur [KDW, 2: 760], melius reformare [KDW, 2: 773; KDW, 6: 56], valeat reformari [KDW, 2: 979], duxerit reformandam [KDW, 2: 1046], cupientes reformacionem [KDM, 1: 186], reformari seu locari [ZDM, 4: 891], ob/ab reformacionem [PU: 572; CDP, 1: 79].

13 There appeared such formulations as: facere meliorem [KDW, 2: 804], cupientes melioracionem [KDM, 1: 150], efficere meliorem/s [ZDM, 1: 18; CDP, 1: pars 2 nr 198, 201], meliorationis incrementum [ZDM, 4: 895], pro melioratione [CDP, 1: pars 2 no 89).

14 On the level of the narrative, a reference to founding appear in forms such as: reformari seu locari [ZDM, 4: 891], locare valeant [KDW, 2: 1085].

${ }^{15}$ In the narrative of one of the diplomas, such formulation was used: pro ampliatione [CDP, I: 89].

${ }^{16}$ In the case of bestowal of the village of Wroncze to the mayor of Lutomiersk, a note appeared: ad maiorem restauracionem civitatis nostre que Luthomirsko nuncupatur [Kilkanaście dokumentów..., no 1].

${ }^{17}$ Quod utilitates nostri Principatus per amplius dilatare cupientes [...] [KDM, 1: 155]; quod proventus et utilitates nostras regales multiplicare cupientes [KDM, 1: 181], [...] in utilitatibus seu fructibus sumeret incrementum [KDM, 1: 186], quod nostri principatus utilitates ac prouentus cupientes peramplius dilitare [KDM, 2: 569], [...] quod prouentus et utilitates nostras regales augere et multiplicare cupientes [ZDM, 1: 28]. 
can find here references to the economic changes that took place in Poland from the beginning of the $13^{\text {th }}$ century, related to the granting of economic immunities and colonization under German law, which in historiography are referred to as melioratio terrae. In relation to prevailing activities, this term is understood as a model of better, comprehensive land management by supporting or inspiring activities aimed at increasing the population, applying better methods in agriculture or intensifying urban life, trade, etc. [Körmendy A. 1995; Zientara B. 1968: 203; Legut-Pintal M. 2017: 179-90]. The activities that make up the melioratio terrae program include any multiplication of benefits or incomes of the inhabitants of a given region or the entire country as a result of the implementation of the provisions contained in the documents. In narratives containing description of the royal intentions to intensify the economic sphere, the theme of care for the proper economic development of the lands under his control, and the awareness of the importance of such activities for the proper functioning of the state and society, was clearly exposed.

Narratives with economic content appeared in documents issued by the royal chancellery throughout the entire reign of Władysław the Elbowhigh. The earliest example is the diploma of May 20, 1292 [CDP, 1: 79], the latest - the royal document of June 18, 1331 [KDM, 1: 186]. This may indicate that including the economic context in the narratives was a typical and practiced phenomenon at that time.

When analyzing narratives containing statements about the ruler's desire to increase the benefits of his subjects or improve the economic condition of the estate, it is worth paying attention to the beneficiaries of the royal grace. They can be divided into three categories. The first, the largest, included inhabitants of royal towns (Kalisz [KDW, 2: 760], Poznań [KDW, 2: 773], Pyzdry [KDW, 6: 56; KDW, 2: 1046], Tczew [PU: 572] , Brześć [CDP, 1: 79], Radziejowa [CDP, 1: 89, 108], Lutomierska [Kilkanaście dokumentów..., no. 1], Szydłowa [KDW, 2: 597], Lublin [KDM, 2: 569], Lipnica [ZDM, 1: 28] and Sącz [KDM, 1: 186]) and one private one, i.e. the bishop's town of Słupca [KDW, 2: 979]. The subject of grants varied, but most often it was about granting permission to found a given center under German law (Radziejów, Lublin, Lipnica, Szydłów), granting privileges or commercial facilities (Kalisz, Słupca, Pyzdry), donation of properties or real estate (Tczew, Lutomiersk Brześć, Radziejów, Sącz) or customs exemptions (Poznań). Moreover, one of the royal documents was intended for the bishop of Poznan, Jan. In 1324 the king promised that his intention to reform Pyzdry with the help of the bishop's subjects would not violate the 
laws of the local Church in any way [KDW, 2: 1046]. It cannot be excluded that, in the mind of the Elbow-high, all activities related to supporting the development of urban centers were supposed to be more favorable to his economic goals.

Including references to the economic sphere in diplomas intended for towns seems to be very symptomatic. The scale of the medieval ruler's interest in urban issues or the course of the urbanization process of his territories was one of the basic determinants of the monarch's care for the economic development of his domain ${ }^{18}$. The ruler's aspirations to improve or intensify urban network fit perfectly into the melioratio terrae program. In the case of towns reorganized in the royal domain, the main goal was to increase the value of these estates, as well as to create or reorganize administrative centers [Luciński J. 1965: 93] necessary for effective internal or foreign policy. The reference to economic themes in the narratives of documents intended for these categories of recipients indicated care for the state of the economy of the entire region, the state and the well-being of all his subjects [Gut A. 2002: 148], which was fulfilling one of the basic tasks of a good ruler. One can also consider whether the references to economic activity did not encourage other entities, e.g. owners of settlements located around a specific urban center, to follow in the footsteps of the monarch.

Narratives containing information about desire to "improve" or increase the benefits of the ruled lands appeared in the Elbow-high's diplomas intended for royal estates. In this respect, permits for the establishment of villages on wastelands in Małopolska were in the lead. Following such motives, the ruler agreed to the creation of a village in the forest near Pieskowa Skała, where the settlement of Sułoszowa (cupientes meliorationem terre nostre Cracouiensis) had previously existed [KDM, 1: 150], for a foundation on the raw root of the settlement on the Uszwica river (utilitates nostri Principatus per amplius dilatare cupientes) (later Rajbrot) [KDM, 1: 155] and in the forest called Hutnica (proventus et utilitates nostras regales multiplicare cupientes) [KDM, 1: 181] where Szklary was established.

The last category of documents, whose narratives contained references to economic issues, were addressed to private audiences (lay and clergy). Two cases can be identified among church entities. One of them was the aforementioned diploma guaranteeing the protection of the king to three male Cistercian monasteries from Wielkopolska, which was to facilitate

${ }^{18}$ More on this topic in: Obara-Pawłowska A. [2014a: 247-54]. 
the allocation of estates owned by these institutions [KDW, 2: 1085], which suffered from various perturbations. The second, chronologically earlier, was intended for Poznań Dominican Nuns and concerned the granting of the village of Stępowo to them in 1299, with the exemption from the obligations of the Polish law [KDW, 2: 804]. Land donations to monastic recipients were not too numerous during the reign of Władysław the Elbow-high, and they can often be explained by political motives [Obara-Pawłowska A. 2014a: 115]. In the narrative of the discussed document, however, there is a significant formulation, not used in other land grants to monasteries, saying that the ruler had in mind ipsius claustri condicionem pro omni nostro posse facere meliorem. The special attention shown to the Poznań Dominican Nuns and the interest in improving the economic condition of their estate indicate the will to continue the monarch's policy towards the sisters. The Dominican Sisters were brought to the capital of Wielkopolska in 1283. It is assumed that in the first period of their functioning in this area, the mendicants remained dependent on their founders - representatives of the Przedpełkowice family - and closely related to the court of Prince Przemysł II, who is considered the guardian of Dominican orders [Wiesiołowski J. 2004: 118]. By issuing his privilege, the Elbow-high appears as a continuator of the protective activity of his predecessor on the Wielkopolska throne, striving to improve the ownership of nuns [Obara-Pawłowska A. 2014a: 140]. In addition, the goal was here to improve the property condition of the Dominican Nuns, i.e. the order closely related to the urban environment. The economic strengthening of this institution could strengthen the position of Poznan itself as a fully developed urban center.

Several documents with the described type of narration were intended for secular recipients, i.e. the knight Gniewomir of Tropie (he obtained the village of Dzierżaniny from prince Władysław along with the consent to transfer it to the German law) [ZDM, 1: 18], the voivode of Kujawy Stanisław (he received three villages from the monarch) [CDP, 1: pars 2, 198, 201], Zdziesław (grant immunity to his three settlements near Lublin) [ZDM, 4: 891] and Dzierżek and Ostasz from Bejsce (permission to transfer their 26 estates to the Środa law, most of which were located in the Lublin region [ZDM, 4: 895].

An analysis of the diplomas issued in the Władysław the Elbow-high's office shows that economic narratives also appeared in the case of properties located in areas whose economy was of particular interest to the monarch. This was the case with the foundation of a few raw root settle- 
ments in the royal domain in the land of Kraków, i.e. Szklary and Rajbrot, and the reorganization of Sułoszowa, located in the same area. These localities were established in the wastelands where deforestration was undertaken ${ }^{19}$. The actions of the ruler also seem to indicate that he was striving to organize new complexes of royal properties in the indicated areas [Obara-Pawłowska A. 2014a: 80]. It was about not only commissioning the foundation of rural settlements, but also establishing new urban centers. In 1326, the king granted town privileges to the aforementioned Lipnica Murowana ${ }^{20}$, located near the Rajbrot settlement. In turn, Sułoszowa is located approximately $20 \mathrm{~km}$ south of the town of Wolbrom, which, according to some historians, could have been elevated to the rank of a town after 1327, during the reign of the Elbow-high [Kiryk F. 1978: 398; Berdecka A. 1982: 36]. In the case of Sułoszowa, it seems equally interesting to link its reorganization ${ }^{21}$ to the use and modernization plans by Władysław of the Pekenstein stronghold, i.e. Pieskowa Skała ${ }^{22}$ [Laberschek J. 2008: 463; 2016: 82]. The reign of this ruler marked the beginning of transformations not only of the castles themselves, but also of the castle's properties, which was manifested, inter alia, in ensuring an appropriate economic base [Laberschek J. 2008: 460-2]. The command to found the village in the immediate vicinity of the castle constituted perfectly a part of this process.

A good example confirming thinking in economic terms, articulated in the narratives of the issued documents, is also the case of the Lublin region. The location of this region on the eastern fringes of the Piast monarchy exposed Lubelskie to frequent invasions by its pagan and schismatic neighbors. This resulted, inter alia, in delay in introducing economic

19 Such was the case of the village of Rajbrot which was created as a result of activities aimed at colonization of forest areas located to the south-east of Bochnia [Mateszew S. 1980: 53-4, 57].

${ }^{20}$ ZDM [1: 28]. About factors which led to this foundation see in: Kiryk F. [2007: 11 etc..].

${ }^{21}$ Contrary to Rajbrot and Szklary, Sułoszowa was not founded on the raw root. We can read from the document of the Elbow-high that the prince, aiming at "amelioration" of the Kraków lands, ordered to reorganize the forest strechted between the castle Pieskowa Skała, with the village of Sułoszowa, up to the borders of the village of Kosmołów (siluam nostram incipiendo a castro dicto Pekensten cum villa dicta Sulossow usque ad metas hereditatis que Cosmalow wlgariter nuncupatur [KDM, 1: 150]). More in: Wojenka M. [2014: 195-6].

${ }^{22}$ A continuator and executor of further modernization of the castle was Casimir the Great who ordered to move this building to a more suitable place, from the Kocica hill to a neighboring hill, about 800 meters far, where the castle is located up to this day [Laberschek J. 2008: 463-4; 2016: 82; Kołodziejski S. 2016: 165-6]. 
reforms related to colonization under the German law. The destruction that was systematically done by the invaders and the feeling of permanent danger connected with it, discouraged church and secular entities from investing in this area [Sochacka A. 1987: 12-3]. The situation changed during the reign of Władysław the Elbow-high. His successive economic decisions with regard to the estates of Lublin include planned activities aimed at economic intensification of this area [more see: Obara A. 2010: 9-40; ObaraPawłowska A., 2014a: 230-2; forthcoming], as expressed in the relevant diplomas. In three documents issued in the years 1311-1317, the prince emphasized that the reason for the economic privileges was the hope to increase the benefits or to reform Lublin and villages located near the town. It can be assumed that the prince was implementing a certain economic plan the aim of which was a fully intended intensification of the economic development of the eastern parts of his domain, with the participation of his faithful and trusted subjects. Such people included Zdziesław - from 1310, Deputy Chancellor of Kraków [Wroniszewski J. 2000: 90; Marzec A. 2006: 108, fn. 444], Maciej of Opatowiec [Froehlichowa Z. 1927-1930: 77-8; Myśliński K. 1962: 13-4; Wyrozumski J. 1974: 7; Nowak B. 1993: 169-70] the recipient of the document of August 15, 1317 intended for Lublin and the brothers Ostasz (from 1326 the Kraków podstoli) and Dzierżek (in the years 1325-1332 a Kraków canon and the parish priest in the St. Florian church in Kraków) from Bejsce [Sochacka A. 2014: 107; Marzec A. 2006: 46]. Men from Bejsce obtained, at the end of November 1317, a permission to transfer their Małopolska estates to the Środa law, including 16 villages located in the Lublin region. The recipients of permits for the reorganization of estates in Lubelskie were among the people associated with the royal court. It is possible that due to their contacts with the ruler, they were aware of the royal intentions towards the eastern border. In this context, it can be argued that the reference to economic content in the documents intended for Lublin addressees was not a coincidence, but rather an emanation of the program of economic transformations in the eastern border of the Piast monarchy ${ }^{23}$ [Obara-Pawłowska A. 2014a: 231]. At the same time, one cannot forget about other activities undertaken by the Elbowhigh in his Lublin estate, which were aimed at strengthening the property of Kazimierz Dolny, another important center of the region. They concerned the process of revindication of properties around this town. It is

${ }^{23}$ More about the engagement of the Elbow-high into the transformation of the economy of Lublin lands in: Obara A. [2010: passim]. 
assumed that before 1325, several villages near Kazimierz, which had been given to the Norbertine nuns of Zwierzyniec, returned to the royal domain [Lalik T. 1967: 179-80; Sochacka A. 1987: 32-3; 2012: 289]. These activities are considered by some historians as a preparation for the town foundation ${ }^{24}$.

\section{CONCLUSIONS}

The use of economic motifs in the narratives of Władysław the Elbowhigh's documents was not accidental. Their appearance was reflected in specific events influencing the economic condition of a given town or region. They can also be read as a sign of the ruler's interest in protection and desire to improve the situation of his subjects ${ }^{25}$. The ruler, striving to give an impulse to develop for a given area, treated all owners unequally (e.g. meliorato terrae mainly concerned the royal domain, it referred to the functionaries of the state apparatus, a favorable supervisor of the clergy, etc.). However, since privileges were granted only to selected, worthy of grace or allies just won by the ruler, could this weaken the thesis on general development motives guiding Władysław the Elbow-high? It seems that not necessarily, because in his actions the ruler could have combined acts of grace with aspirations of a broader nature.

In research on the role and significance of economic motifs in the narratives of Łokietek's documents, most problematic is the small number of them (27 cases, with just over 300 diplomas prepared in the Władysław's office, preserved to our times). However, it should be remembered that economic content was more often used in the case of documents intended for specific categories of property. This finding allows for a slightly different assessment of the quantitative issues. We have 10 documents relating to royal estates. Economic references in the narrative appeared in 3 of them (all of them concern Małopolska estates). The issues of permits for foundation of urban centers, donation of land estates to towns, etc., appeared in 69 royal documents, in 14 cases of which the issue of a given privilege was accompanied by its economic justification. The above figures are still

${ }^{24}$ Literature devoted to the possibility of foundation of Kazimierz Dolny during Władysław the Elbow-high's rule: Obara-Pawłowska A. [2014a: 301-2].

${ }^{25}$ About the beliefs concerning the role of the ruler in the economy see in.: Nederman C.J. [2001: 51-69]; Kelly J.M. [2006:, 174]; Dubel L. [2008: 17]. 
not very impressive, but they are a point of reference. It seems that one of the reasons why the discussed themes are not often referred to in the narratives is the observed gradual transfer of economic content to the arengas of documents issued by Władysław the Elbow-high. Preambles containing references to economic issues, or more precisely - emphasizing the importance of the ruler in the economic sphere - began to appear more and more often in documents issued after the royal coronation of the monarch ${ }^{26}$. In turn, out of 27 narratives containing references to the economy, 9 appeared in documents published after $1320^{27}$. The phenomenon of including economic threads in the arengas should be associated with the change in attitude to the economic sphere which was less and less often perceived as a source of sin, and with the increasingly bold emphasis on the necessity for the ruler to take active steps in this area. References to the aforementioned issues were considered worthy of being included in the most solemn part of the document, which was the arenga [Nowakowski T. 2007: 96]. At the same time, deliberate placing of economic content in the narratives or arenas of royal documents weakens the stereotype of the Elbowhigh as a ruler completely indifferent to economic matters, present especially in older literature.

Regardless of the quantitative issues, it should be emphasized that narratives containing economic motifs are a good source for learning about the economic awareness of the medieval ruler. In order to fully explain their role and meaning and dispel any ambiguities, it is necessary to compare references to the economic sphere appearing in the documents of other Piast rulers, both predecessors and successors of Władysław the Elbow-high, and to confront the obtained results with the knowledge of monarchical ideology in the studied period.

\title{
REFERENCES
}

\author{
Abbreviations of literary sources \\ Annales - Długosz J., Annales seu cronicae incliti Regni Poloniae \\ CDP - Codex diplomaticus Poloniae \\ KDM - Kodeks dyplomatyczny Matopolski
}

${ }^{26}$ Economic motifs can also be found in the arengas of 11 documents issued after the royal coronation of Władysław [Obara-Pawłowska A. 2014b: 1052-6].

271322 [CDP, 1: 107]; 1324 [KDW, 2: 1044, 1046]; 1326 [KDW, 2: 1068; ZDM, 1: 28]; 1327 [KDW, 2: 1085]; 1329 [KDM, 1: 181; KDM, 2: 596]; 1331 [KDM, 1: 186]. 
KDW - Kodeks dyplomatyczny Wielkopolski

Kilkanaście dokumentów - Maleczyński K., Kilkanaście dokumentów Wtadystawa Łokietka z lat 1296-1329

PSB - Polski stownik biograficzny

PU - Pommerellisches Urkundenbuch

ZDM - Zbiór dokumentów małopolskich

\section{Sources}

Chronicon Aulae regiae, (1882-1884), [in:] Emler J. (ed.), Fontes Rerum Bohemicarum, t. 4, Praha.

Codex diplomaticus Poloniae, t. 1, (1847), Wyd. L. Ryszczewski, A. Muczkowski, Warszawa.

Długosz J., Annales seu cronicae incliti Regni Poloniae, lib. 9, (1978), Budkowa Z. et. al. (ed.), Danuta Turkowska D (text reviewed and moderavit), Pieradzka K. (comments), Państwowe Wydawnictwo Naukowe, Varsaviae.

Kodeks dyplomatyczny Matopolski, t. 1-2, (1876-1886), Piekosiński F. (published and annoted), Akademia Umiejętności, Kraków.

Kodeks dyplomatyczny Wielkopolski, t. 2, (1878), Zakrzewski I. (publisher), Nakładem Biblioteki Kórnickiej, Poznań.

Kodeks dyplomatyczny Wielkopolski, t. 6, (1982), Gąsiorowski A, H. Kowalewicz (eds.), Państwowe Wydaw. Naukowe, Warszawa-Poznań.

Maleczyński K. (1961), Kilkanaście dokumentów Wtadystawa Łokietka z lat 1296-1329, „Studia Źródłoznawcze", 6, 129-139.

Petri de Dusburg, Chronicon terre Prussiae, (1861), [in:] Hirsch T., Töppen M., Strehlke F. (eds.), Scriptores Rerum Prussicarum, Verlag von S. Hirzel, Leipzig, 21-219.

Pommerellisches Urkundenbuch, (1882), wyd. M. Perlbach, Westpreussischen Geschichtsverein Gdańsk.

Rocznik kapituły poznańskiej, (1962), Kürbis B. (ed.) „Monumenta Poloniae Historica, Series Nova, 6, PWN, Warszawa.

Zbiór dokumentów małopolskich, cz. 1, 4, (1962-1969), wyd. I. Sułkowska-Kuraś, S. Kuraś, Zakład Narodowy im. Ossolińskich, Wrocław.

\section{Literature}

Barciak A. (1988), Arengi i narracje dokumentów Przemysta Ottokara II dla miast i mieszczaństwa, [in:] Michalkiewicz S. (ed.), Miasta w ciąu wieków. Wybrane problemy, Śląski Instytut Naukowy, Katowice, 35-44.

Berdecka A. (1982), Lokacje i zagospodarowanie miast królewskich w Małopolsce za panowania Kazimierza Wielkiego (1333-1370), Zakład Narodowy im. Ossolińskich, Wrocław.

Bielińska M. (1967), Kancelarie i dokumenty wielkopolskie XIII wieku, Zakład Narodowy im. Ossolińskich, Wrocław.

Brust M. (1986), Początki i rozwój miast w dorzeczu środkowej Warty i dolnej Wetny, Roczniki Historyczne, 52, 1-54.

Brust M. (1993), Rogoźno w czasach najdawniejszych i w średniowieczu, [in:] Boras Z. (ed.), Dzieje Rogoźna, Wydawnictwo „Lega”, Poznań, 7-63.

Brust M. (2010), Etapy rozwoju osadnictwa wczesnośredniowiecznego na obszarze zespołu przedlokacyjnego w Rogoźnie od IX do końca XIV wieku, Studia Lednickie, 10, 57-87.

Dubel L. (2008), Wprowadzenie, [in:] Kruk M. (transl.), Jan z Salisbury, Policraticus albo o paplaninie dworaków i przekazach filozofów, Oficyna Wydawnicza "Verba”, Lublin 2008, 9-34.

Dzieje Stupcy (1996), Szczepański B. (ed.), Wydawnictwo WBP, Poznań. 
Froehlichowa Z. (1927-1930), Z dziejów organizacji władz miejskich m. Lublina do końca XVII wieku, Pamiętnik Lubelski, 1, 83-115.

Gładyszówna J. (1933), Ludwik Wittelsbach margrabia brandenburski wobec Polski (Czasy Wtadystawa Łokietka), Roczniki Historyczne, 9(1), 1-45.

Gut A. (2002), Formularz dokumentów książą zachodniopomorskich do połowy XIV wieku, Wydawnictwo Naukowe Uniwersytetu Szczecińskiego, Szczecin.

Hutnictwo na ziemiach polskich (1992), Czermiński J. (ed.), Stowarzyszenie Inżynierów i Techników Przemysłu Hutniczego, Katowice.

Jurek T. (2005), Przebieg lokacji Poznania, [in:] Kurnatowska Z., Jurek T. (ed.) Civitas Posnaniensis. Studia z dziejów średniowiecznego Poznania, Wydawnictwo PTPN, Poznań, 173-191.

Jurek T. (2006), Dziedzic Królestwa Polskiego książe głogowski Henryk (1274-1309), Avalon, Kraków.

Karasiewicz W. (1965), Wodpowiedzi K. Jasińskiemu na temat: Rola polityczna możnowładztwa wielkopolskiego w latach 1284-1314, Roczniki Historyczne, 31, 261-270.

Kelly J.M. (2006), Historia zachodniej teorii prawa, Wydawnictwo WAM, Kraków.

Kiryk F. (1978), Pozostałe miasta regionu olkuskiego, [in:] Kiryk F., Kołodziejczyk R. (eds.), Dzieje Olkusza i regionu olkuskiego, t. I, Państwowe Wydawnictwo Naukowe, Warszawa, 341-412.

Kiryk F. (2007), Najdawniejsze dzieje Lipnicy Murowanej (XIII-XVI wieku), [in:] Smołucha J. (ed.), Lipnica Murowana. Gród króla Władysława Łokietka, Księgarnia Akademicka, Kraków, 9-28.

Kołodziejski S. (2016), Budownictwo obronne, [in:] Partyka J. (ed.), Monografia Ojcowskiego Parku Narodowego. Dziedzictwo kulturowe, Ojcowski Park Narodowy. Muzeum im. Profesora Władysława Szafera, Ojców, 157-180.

Körmendy A. (1995), Melioratio terrae. Vergleichende Untersuchungen über die Siedlungsbewegung im östlichen Mitteleuropa im 13.-14. Jahrhundert, Wydawnictwo PTPN, Poznań.

Kotecki R. (2020), Żydzi, świętokradcy i pokój książęcy. Wokót instytucji protekcji monarszej w Polsce piastowskiej, [in:] Michałowski R., Pac G. (eds.) Oryginalność czy wtórność? Studia poświęcone polskiej kulturze politycznej i religijnej (X-XIII wiek), Wydawnictwo Uniwersytetu Warszawskiego, Warszawa, 27-75.

Kuraś S. (1971), Przywileje prawa niemieckiego miast i wsi małopolskich XIV-XV wieku, Zakład Narodowy im. Ossolińskich, Wrocław.

Kutrzeba S., Ptaśnik J. (1910), Dzieje handlu i kupiectwa krakowskiego, Rocznik Krakowski, 14, 1-183.

Laberschek J. (2008), Bezpośrednie zaplecze gospodarcze zamków województwa krakowskiego do połowy XVI wieku, [in:] Smołucha J., Waśko A., Graff T., Nowakowski P.F. (eds.), Historia vero testis temporum. Księga jubileuszowa poświęcona Profesorowi Krzysztofowi Baczkowskiemu w 70. rocznice urodzin, Towarzystwo Naukowe Societas Vistulana, Kraków, 459-476.

Laberschek J. (2016), Ojców i okolice do połowy XVI wieku, [in:] Partyka J. (ed.), Monografia Ojcowskiego Parku Narodowego. Dziedzictwo kulturowe, Ojcowski Park Narodowy. Muzeum im. Profesora Władysława Szafera, Ojców, 75-105.

Lalik T. (1967), Rec.: H. Rutkowski, Kazimierz Dolny. Krajobraz i architektura, Warszawa 1965, Kwartalnik Historii Kultury Materialnej, 15(1), 179-180.

Legut-Pintal M. (2017), Śląski model melioratio terrae na przykładzie ziemi nysko-otmuchowskiej i Pogórza Kaczawskiego, [in:] Adamska D., Chrzan K., Pankiewicz A. (eds.), Cum gratia et amicitia. Studia z dziejów osadnictwa dedykowane Pani Profesor Marcie Mtynarskiej- 
Kaletynowej z okazji 65-lecia działalności naukowej, Instytut Archeologii i Etnologii Polskiej Akademii Nauk, Ośrodek Badań nad Kulturą późnego Antyku i Wczesnego Średniowiecza, Wrocław, 179-194.

Luciński J. (1965), Lokacje wsi i miast monarszych w Małopolsce do 1385 r., Czasopismo Prawno-Historyczne, 17(2), 53-122.

Maleczyński K., Bielińska M., Gąsiorowski A. (1971), Dyplomatyka wieków średnich, Państwowe Wydawnictwo Naukowe, Warszawa.

Marzec A. (2006), Urzędnicy małopolscy w otoczeniu Wtadysława Łokietka i Kazimierza Wielkiego (1305-1370), Wydawnictwo Towarzystwa Naukowego „Societas Vistulana”, Kraków.

Mateszew S. (1980), Osadnictwo i stosunki własnościowe do końca XV wieku, [in:] Kiryk F., Ruta Z. (eds.), Bochnia - dzieje miasta i regionu, Urząd Miasta Bochni, Bochnia, 42-77.

Myśliński K. (1962), Wójt dziedziczny u rada miejska w Lublinie 1317-1504, Wydawnictwo Lubelskie, Lublin.

Myśliński K. (1964), Początki miasta Kraśnika i Urzędowa na tle rozwoju południowej Lubelszczyzny, [in:] Myśliński K., Szaflik R. (eds.), Z dziejów powiatu kraśnickiego, Wydawnictwo Lubelskie, Lublin, 11-27.

Nederman C.J. (2001), The Monarch and the Marketplace: Economic Policy and Royal Finance in Wiliam Pagula's Speculum regis Edwardi III, History of Political Economy, 32(1), 51-69.

Nowak B. (1993), Maciej z Opatowca, [in:] Radzik T., Skarbek J., Witusik A.A (eds.), Stownik biograficzny miasta Lublina, Wydawnictwo UMCS, Lublin, 169-170.

Nowak T. (1989), Znaczenie budowli obronnych w Wielkopolsce, Kujawach, ziemi dobrzyńskiej, tęczyckiej i sieradzkiej w dziataniach wojennych w XIV w. (1313-1385), Acta Universitatis Lodziensis Folia Historica, 36, 33-75.

Nowakowski T. (2007), Elementy potocznej myśli ekonomicznej w arengach polskich dokumentów w XII-XIV wieku, [in:] Zyglewski Z. (ed.), Polska w kręgu polityki, kultury i gospodarki europejskiej. Ksiegga pamiatkowa z okazji 70-lecia urodzin prof. Maksymiliana Grzegorza, Wydawnictwo Uniwersytetu Kazimierza Wielkiego, Bydgoszcz, 91-105.

Obara A. (2010), Gospodarka a polityka. Decyzje gospodarcze Wtadysława Łokietka na obszarze wschodniego pogranicza, Res Historica, 40, 9-40.

Obara-Pawłowska A. (2014a), Polityka gospodarcza Wtadystawa Łokietka, Wydawnictwo UMCS, Lublin.

Obara-Pawłowska A. (2014b), Treści ekonomiczne w arengach dokumentów Władystawa Łokietka, [in:] Sochacka A., Jusiak P. (eds), Scientia nihil est quam veritatis imago. Studia ofiarowane Profesorowi Ryszardowi Szczygłowi w siedemdziesięciolecie urodzin, Wydawnictwo UMCS, Lublin, 1049-1060.

Obara-Pawłowska A. [forthcoming], Inicjatywy gospodarcze ostatnich Piastów na obszarze ziemi lubelskiej. Planowe działania czy realizacja doraźnych potrzeb?

Olejnik K. (2002), Działania wojenne na obszarze Wielkopolski i ziemi lubuskiej w dobie państwa piastowskiego (X-XIV wiek), [in:] Wróblewski W. (ed.), Działania militarne w Wielkopolsce i na ziemi lubuskiej, "Comandor", Warszawa, 33-72.

Potkański K. (1965), Walka o Poznań 1306-1312, [in:] Potkański K. (ed.), Lechici, Polanie, Polska. Wybór pism, Państwowe Wydawnictwo Naukowe, Warszawa, 474-505.

Preissner A. (1965), Dokumenty Wtadystawa Łokietka. Chronologiczny spis, regesty i bibliografia publikacji, Rocznik Biblioteki PAN w Krakowie, 11, 197-296.

Rymar E. (1979), Rywalizacja o ziemię lubuską i kasztelanię międzyrzecką w latach 1319-1326 ze szczególnym uwzględnieniem stosunków pomorsko-śląskich, Sobótka, 34(4), 473-496.

Rymar E. (2000), Polsko-litewska wyprawa zbrojna do Marchii Brandenburskiej w 1326 r., Nadwarciański Rocznik Historyczno-Archiwalny, 7(1), 21-44. 
Skulimowski A., Skulimowski M. (1958), Magister Mikołaj - nadworny lekarz książąt wielkopolskich w drugiej pot. XIII i początkach XIV w., Archiwum Historii Medycyny, 21 (3-4), 285-290.

Słownik historyczno-geograficzny ziem polskich w średniowieczu (2020), T. Jurek, S. Prinke (eds.) http:/ / www.slownik.ihpan.edu.pl/index.php, accessed on 10.09.2020.

Sochacka A. (1987), Wtasność ziemska w województwie lubelskim w średniowieczu, Uniwersytet Marii Curie-Skłodowskiej, Lublin.

Sochacka A. (2012), Najdawniejsze dzieje parafii w Kazimierzu Dolnym, [in:] Pleszczyński A., Sobiesiak J., Tomaszek M., Tyszka P. (eds.), Historia Narrat. Studia mediewistyczne ofiarowane Profesorowi Jackowi Banszkiewiczowi, Wydawnictwo UMCS, Lublin, 277-292.

Sochacka A. (2014), Posiadłości Lewwartów w Lubelskiem w późnym średniowieczu, [in:] Sochacka A. (ed.), Regimen, dominium, societas Nobilium. Z dziejów gospodarki, administracji i polityki w Lubelskiem w średniowieczu, Wydawnictwo UMCS, Lublin, 103-127.

Tanaś K. (2006), Społeczeństwo wielkopolskie w procesie ksztattowania tożsamości regionalnej (1202-1314), Wydawnictwo Poznańskie, Poznań.

Tomaszewski J. (1981), Polityka gospodarcza, [in:] Mączak A. (ed.), Encyklopedia historii gospodarczej Polski do 1945 roku, Wiedza Powszechna, Warszawa, 94-95.

Wiesiołowski J. (2004), Dominikanki poznańskie w kręgu mecenatu Przedpełkowiców, Kronika Miasta Poznania, 3, 109-119.

Wojenka M. (2014), Pradzieje i średniowiecze w świetle źródeł archeologicznych, [in:] Maciejowski W. (ed.), Monografia gminy Sułoszowa, Centrum Kultury w Sułoszowej, Instytut Geografii i Gospodarki Przestrzennej UJ, Kraków, 183-203.

Wroniszewski J. (2000), Prałaci kolegiaty wiślickiej w XIV wieku. Pochodzenie i drogi awansu, [in:] Radzimiński A. (ed.), Duchowieństwo kapitulne w Polsce średniowiecznej i wczesnonowożytnej: studia nad pochodzeniem i funkcjonowaniem elity kościelnej, Wydawnictwo Uniwersytetu Mikołaja Kopernika, Torun, 84-99.

Wyrozumski J. (1974), Maciej, w: PSB, 19, Zakład Narodowy im. Ossolińskich, Wrocław, 7.

Wyrwa A.M. (1995), Procesy fundacyjne wielopolskich klasztorów cysterskich linii altenberskiej, Instytut Historii Uniwersytetu im. Adama Mickiewicza, Poznań.

Wyrwa A.M. (1999), Zemsko-Bledzew, [in:] Wyrwa A.M., Strzelczyk J., Kaczmarek K. (eds.), Monasticon Cisterciense Poloniae, t. II: Katalog męskich klasztorów cysterskich na ziemiach polskich i dawnej Rzeczypospolitej, Wydawnictwo Poznańskie, Poznań, 370-386.

Zajączkowski S. (1929), Polska a Zakon Krzyżacki w ostatnich latach panowania Władysława Łokietka, nakł. Towarzystwa Naukowego, Lwów.

Zientara B. (1952), Ze studiów nad historią techniki polskiego hutnictwa żelaznego do XVII wie$k u$, Przegląd Historyczny, 43(2), 195-242.

Zientara B. (1954), Dzieje małopolskiego hutnictwa żelaznego XIV-XVII w., Państwowe Wydawnictwo Naukowe, Warszawa.

Zientara B. (1968), Konflikty narodowościowe na pograniczu niemiecko-stowianskim w XIIIXIV w. i ich zasięg społeczny, Przegląd Historyczny, 49(2), 197-213.

Dr Anna Obara-Pawłowska is employed as an assistant professor at the Department of Ancient and Medieval History at the Institute of History of the Marie Curie-Skłodowska University in Lublin. Her research interests focus on the economic history of Polish lands in the 13th and 14th centuries (monograph: Economic Policy of Wtadystaw the Elbow-high [Polityka gospodarcza Wtadystawa Łokietka], Wydawnictwo UMCS, Lublin 2014, pp. 441; 
Economic Content in the Arengas of the Documents of Wtadystaw the Elbow-high [Treści ekonomiczne w arengach dokumentów Wtadystawa Łokietka], [in:] Scientia nihil est quam veritatis imago. Studia ofiarowane Profesorowi Ryszardowi Szczygłowi w siedemdziesięciolecie urodzin, eds. A. Sochacka and P. Jusiak, Lublin 2014, pp. 1049-1060; Polish and Hungarian Economic Relations in the Middle Ages (from the Second Half of the 13th Century to the End of 14th Century), in: Hungaro-Polonica. Young Scholars on Medieval Polish-Hungarian Relations, eds. D. Bagi, G. Barabas, Z. Mate, Pecs 2016, pp. 225-263) and on the writings of Jan Długosz (The Image of the Wallachians in the Writings of Jan Dtugosz [Obraz Wotochów w piśmiennictwie Jana Dtugosza], “Balcanica Posnaniensia. Acta et studia” vol. 24 (2017) pp. 197-220; Jan Dtugosz's Position Towards the Foreign Ruler on the Polish Throne [Stanowisko Jana Dtugosza wobec cudzoziemskiego władcy na tronie polskim], „Średniowiecze Polskie i Powszechne” no 11 (15), 2019, pp. 119-145). 